\title{
Theorising Order in the Shadow of War: The Politics of International Legal Knowledge and the Justification of Force in Modernity
}

\author{
Hendrik Simon
}

\begin{abstract}
The History of International Law lacks systematic studies on the link between legal scholars and practices of justifying war. This missing analytical link has for a long time given the impression that legal scholars describe 'state practice' in an 'objective', unpolitical way. Contradicting this impression, the chapter turns to the politics of legal scholars in the genesis of the modern war discourse. It reflects on the fateful entanglement of violence, law and politics, but nevertheless distinguishes between 'objective' and 'political' scholarship on the basis of Hans Kelsen's work. Furthermore, the chapter illustrates the politicisability of legal scholars in selected historical cases of the 'long 19th century' (1789-1918). In all cases, two hearts pounded in lawyers' chests: one scientific, the other political. As will be shown, the modern war discourse is shaped by a phenomenon that enables scholars to expand the intrinsic limits to the political instrumentalisation of law: 'multi-normativity'.
\end{abstract}

\section{Keywords}

politics and law - International Legal Scholarship - modern war discourse - Ius ad Bellum - 'long 19th Century' - multi-normativity - nationalism - Kelsen

Introduction: The Politics of Legal Knowledge - A Missing Link in the History of War Justifications

Paradoxically or not, at the core of the discipline of (the History of) International Law lies a phenomenon of a highly political nature: the entanglement 
of the justification and the critique of violence. ${ }^{1}$ Hence, the historical reconstructions of war discourses have been constitutive for the emergence of international law as a scientific discipline. ${ }^{2}$ However, an analytical imbalance in favour of doctrinal histories can clearly be identified. To fill the gap between practice and theory is highly important for the further orientation of the History of International Law in its own right. ${ }^{3}$ As part of such an endeavour, the present chapter focusses on a specific aspect of the analytical gap between theory and practice: It reflects on the politics of legal knowledge in historical war discourses.

The History of International Law is not only lacking insights into the role of norms in political practices of justifying war ${ }^{4}$ - it also lacks systematic and comparative studies on the link between legal scholars and politics in this particular policy field. ${ }^{5}$ Legal scholars are the primary authors of writing legal histories - and at the same time, they are their primary historical sources. For a long time, this dual role has given the impression that doctrine describes and systematises 'state practice' in an 'objective' way. ${ }^{6}$ But instead, the resulting doctrinal histories and narratives largely miss reflection on what Reinhart Koselleck has called a scholar's personal Standpunkt ('viewpoint') and its influence on the way scholars 'observe' international law. ${ }^{7}$

If legal scholars' preferences are to be taken more seriously in the policy field of war and peace, a couple of fundamental questions arise: Firstly and

1 Brock, Lothar and Hendrik Simon, eds. The Justification of War and International Order. From Past to Present (Oxford: Oxford University Press, 2021).

2 Neff, Stephen C. War and the Law of Nations: A General History (Cambridge: Cambridge University Press, 2005).

3 Tischer, Anuschka. Offizielle Kriegsbegründungen in der Frühen Neuzeit: Herrscherkommunikation in Europa zwischen Souveränität und korporativem Selbstverständnis (Berlin: LITVerlag, 2012); Payk, Marcus M. Frieden durch Recht? Der Aufstieg des modernen Völkerrechts und der Friedensschluss nach dem Ersten Weltkrieg (Berlin: De Gruyter, 2018); Benton, Lauren. 'Beyond Anachronism: Histories of International Law and Global Legal Politics'.Journal of the History of International Law 21(1) (2019), 7-40, doi: 10.1163/15718050-12340100.

4 Brock/Simon, Justification of War 2021 (n. 1).

5 A textbook example is Grotius' work for the Dutch East India Company in the 17th century, see Van Ittersum, Martine Julia. 'The Long Goodbye: Hugo Grotius' Justification of Dutch Expansion Overseas, 1615-1645'. History of European Ideas 36(4) (2010), 386-411; and Hathaway, Oona A. and Scott Shapiro. The Internationalists: How a Radical Plan to Outlaw War Remade the World (New York: Simon \& Schuster, 2017), chapter 1.

6 See also the critique in Carty, Anthony. 'Doctrine versus State Practice', in Oxford Handbook of the History of International Law, eds. Bardo Fassbender and Anne Peters (Oxford: Oxford University Press, 2012), 972-996.

7 Koselleck, Reinhart. Vergangene Zukunft: Zur Semantik geschichtlicher Zeiten (Frankfurt am Main: Suhrkamp, 1oth ed. 2017). 
fundamentally, which role do politics play in the shaping of discourses on war and international order by legal scholars? Secondly, do scholars 'objectively' anticipate, accompany or synthesise ${ }^{8}$ the debates? Or are they themselves political actors in their legal interpretation of certain cases - and if so: for what reason? Thirdly, which normative concepts shape their political agenda of justifying or criticising the use of force? Do they refer to law or do they try to by-pass it?

Reflecting on these questions in historical context seems decisive for the investigation of perhaps 'the most difficult problem of the scientific treatment of international law in its history,' ${ }^{9}$ the relationship between political practice and international legal doctrine or, in other words: the 'power-knowledge nexus' 10 in the legal history of war discourses. Far from being able to offer general or even final answers to this problem here, the chapter addresses this nexus, and it does so in the following way: It first develops a distinction between 'objective' and 'political' scholars on the basis of Hans Kelsen's work (section 2). It then turns to concrete case studies of the 'long 19th century' (section 3) (3.1: French Revolutionary Wars; 3.2: German Unification Wars; 3.3: Russo-Turkish Wars), before some conclusions from these case studies are summarised in a broader historical outlook (section 4).

The chapter's central thesis is that throughout modernity (1789 onwards), international lawyers have been exposed to a tension between the values and norms of the international legal community and national political interests. This has tended to politicise legal scholarship. How this tension came about will be illustrated with historical examples: To the extent that it corresponded to their political aims, the lawyers in the focus of this chapter referred to positive law and tried to interpret it according to their political preferences. However, where it appeared useful, they referred to different normative orders, which competed for authority in debates on the legitimacy of force.

As will be argued, this 'multi-normativity'll shapes the entire modern war discourse down to the present day, thus providing a useful political instrument

8 Janssen, Wilhelm. Die Anfänge des modernen Völkerrechts und der neuzeitlichen Diplomatie: Ein Forschungsbericht (Stuttgart: Metzler, 1965).

9 Steiger, Heinhard. 'Ius belli in der Völkerrechtsgeschichte - Universelle Geltung oder Beschränkung auf „anerkannte Kulturvölker“?', in Legalität, Legitimität und Moral. Können Gerechtigkeitspostulate Kriege rechtfertigen?, eds. Thomas Bruha, Sebastian Heselhaus and Thilo Marauhn (Tübingen: Mohr Siebeck, 20o8), 59-98, 62.

10 Foucault, Michel. L'archéologie du savoir (Paris: Gallimard, 1969).

11 Vec, Miloš. 'Multinormativität in der Rechtsgeschichte', in Jahrbuch 2008 (Berlin: BerlinBrandenburgische Akademie der Wissenschaften, 2009), 155-166; Duve, Thomas. 'Was ist "Multinormativität"? Einführende Bemerkungen'. Rechtsgeschichte - Legal History 25 (2017), 88-101. 
for jurists to circumvent the authority of law if deemed necessary. How did the ambivalence between legal scholarship and politics develop in the 'long 19th century' (1789-1918), the birth era of both modern war discourse and modern international order? This question is at the heart of the present chapter.

2

\section{Legal Scholarship as a Political Vocation? Ordering War between Scientific Impartiality and 'National' Interests}

In 1951, Hans Kelsen published an article in The American Political Science Review entitled 'Science and Politics' (the dichotomy is already revealing). Kelsen stated 'that the search for truth, which is the essential function of science, should not be influenced by political interests'; he characterised the latter as 'a function of will. ${ }^{12}$ Echoing Immanuel Kant's normative telos of positive law and thus positioning himself in the liberal tradition of ius contra bellum, ${ }^{13}$ Kelsen argued that avoiding 'the mingling of these two heterogeneous spheres [- the legal and the political -] is as essential for the preservation of the scientific character of jurisprudence as the separation of science from politics is a vital condition for the existence of all independent science'; Kelsen concluded that the

postulation of the separation of the science of positive law from politics means that the legal scientist, in describing his object, must refrain from political value judgments as judgments referring to norms other than norms of positive law, especially from evaluating his object as just or unjust. ${ }^{14}$

This is a textbook definition of the positivist legal scientist in the spirit of Kant's legal philosophy: Accordingly, the emergence of positive law is not only the best evidence for the emergence of 'objective' truth, ${ }^{15}$ the reference to positive law is also the best evidence for an 'objective' legal scientist.

12 Kelsen, Hans. 'Science and Politics'. The American Political Science Review 45(3) (1951), 641-661, 641.

13 Kelsen, Hans. Peace through Law (Chapel Hill: The University of North Carolina Press, 1944).

14 Kelsen, Science 1951 (n. 12), 661.

15 Kleingeld, Pauline. 'What do the Virtuous Hope for? Re-reading Kant's Doctrine of the Highest Good', in Proceedings of the Eighth International Kant Congress: Memphis, 1995, eds. Hoke Robinson (Milwaukee: Marquette University Press, 1995). On Kelsen's project of positivism, see also García-Salmones Rovira, Mónica. The Project of Positivism in International Law (Oxford: Oxford University Press, 2013), chapters 4-6. 
However, in an earlier article published in the Juristische Wochenschrift in 1929, Kelsen had expressed scepticism about legal scholars' actual political independence. He feared that public law scholarship provided 'the 'objectivity' that no politics is able to generate on its own'. Kelsen assumed that international legal scholarship in his time acted as a mouthpiece for the powerful by presenting political interests 'as what is objectively right. ${ }^{\prime}$ With this, Kelsen had developed a real-typical photonegative of the ideal-typical, positivist legal scholar characterised in his later article of 1951. With his deep concern for the politicisability of international legal scholarship as a political instrument of scientific justification, Kelsen proved that he was by no means a utopian, whose pure doctrine of law existed only beyond the realities of the political world. Rather, by pointing to the politicisability of legal scholarship, Kelsen anticipated a core statement of current critical legal theory: ${ }^{17}$ Norms and lawyers 'both justify and enable the critique of established practices. ${ }^{18}$

Here, an important caveat to Kant's project of international legalisation was voiced through Kelsen's criticism: More law is not necessarily better law. Legalisation is not necessarily an evidence for an objective 'progress' in the sense of Kant's telos. Rather, law is always politicisable, part of political projects - even a political project itself (demanded by reason), as Walter Benjamin put it. ${ }^{19}$ The professional lawyer is ultimately always political. This does not only apply to 'first order'scholars in close proximity to political or legal practice, but also to 'second order' scholars who keep their critical academic distance from practice. ${ }^{20}$ For neither are universities or academic institutes

16 Kelsen, Hans. 'Juristischer Formalismus und Reine Rechtslehre'. Juristische Wochenschrift 58(3) (1929), 1723-1726, 1723; see also Bernstorff, Jochen von. 'International Legal Scholarship as a Cooling Medium in International Law and Politics'. European Journal of International Law 25(4) (2014), 977-99o, 977, doi: 10.1093/ejil/chuo73.

17 Carty, Anthony. 'Critical International Law: Recent Trends in the Theory of International Law'. European Journal of International Law 2(1) (1991), 1-27; Singh, Prabhakar and Benoît Mayer, eds. Critical International Law. Postrealism, Postcolonialism, and Transnationalism (Oxford: Oxford University Press, 2014).

18 Koskenniemi, Martti. 'What is Critical Research in International Law? Celebrating Structuralism'. Leiden Journal of International Law 29(3) (2016), 727-735, 731.

19 Benjamin, Walter. 'Critique of Violence', in Walter Benjamin, Reflections: Essays, Aphorisms, Autobiographical Writings, ed. Peter Demetz (Boston: Harcourt, 1978), 277. See also Brock, Lothar and Hendrik Simon. 'Die Selbstbehauptung und Selbstgefährdung des Friedens als Herrschaft des Rechts'. Politische Vierteljahresschrift 59(2) (2018), 269-291.

20 For the distinction between 'first order' and 'second order' scholarship see Bernstorff, Cooling Medium 2014 (n. 16), 99o. 
apolitical spaces, nor can scholars isolate themselves from the historical, sociopolitical, or economic contexts in which they think and act. ${ }^{21}$

Much in this vein, Anne Peters has stated convincingly that a 'complete valuefree academic activity appears impossible, because any kind of statement and any interpretation are pre-structured by the speaker's Vorverständnis' (preliminary understanding). ${ }^{22}$ Even legal positivism may be regarded as a political project. As Benedict Kingsbury has argued with reference to Lassa Oppenheim, it is supported normatively 'as being the best conception of law for the realization of higher normative goals relating to peace, order, certain forms of justice, and the legal control of violence. ${ }^{23} \mathrm{Or}$, in Oppenheim's own words: 'The science of international law ... is merely a means to certain ends outside itself.'24

Accordingly, Martti Koskenniemi concludes: 'The choice is not between law and politics, but between one politics of law, and another. Everything is at stake, but not for everyone. 25 This is also due to the fact that the decision on what is scholarly 'objective' and which legal theories and sources are accepted depends - like everything created by humans - on historical context. ${ }^{26}$ The very existence of different theoretical schools, ${ }^{27}$ the rise and fall of scholarly authority, of mainstreams and orthodoxies, foster Foucauldian scepticism towards an impartial genesis of knowledge in underlining the inner and outer 'politics of expertise. ${ }^{28}$ There is no escape from politics in the science of law.

21 Koselleck, Vergangene Zukunft 2017 (n. 7); Foucault, L'archéologie 1969 (n. 10); Weber, Max. 'Wissenschaft als Beruf', in Max Weber, Gesamtausgabe, vol. 1, eds. Birgit Morgenbrod, Wolfgang J. Mommsen and Wolfgang Schluchter (Tübingen: Mohr Siebeck, 1992); Horkheimer, Max. Traditionelle und kritische Theorie: Fünf Aufsätze (Frankfurt am Main: Fischer, 1992).

22 Peters, Anne. 'International Legal Scholarship under Challenge', in International Law as a Profession, eds. Jean d'Aspremont, Tarcisio Gazzini, André Nollkaemper and Wouter Werner (Cambridge: Cambridge University Press, 2017), 117-159, 129.

23 Kingsbury, Benedict. 'Legal Positivism as Normative Politics: International Society, Balance of Power and Lassa Oppenheim's Positive International Law'. European Journal of International Law 13(2) (2002), 401-436. On Oppenheim's project of positivism, see also García-Salmones, Project of Positivism 2013 (n. 15), chapter 2.

24 Oppenheim, Lassa. 'The Science of International Law: Its Tasks and Method'. American Journal of International Law 2(2) (1908), 313-356, 314, quoted after Kingsbury, Legal Positivism 2002 (n. 23), 403.

25 Koskenniemi, Martti. 'International Law in Europe: Between Tradition and Renewal'. European Journal of International Law 16(1) (2005), 113-124, 123.

26 Peters, Scholarship 2017 (n. 22), 134.

27 For an overview, see Orford, Anne and Florian Hoffmann, eds. The Oxford Handbook of the Theory of International Law (Oxford: Oxford University Press, 2016).

28 Kennedy, David W. 'The Politics of the Invisible College: International Governance and the Politics of Expertise'. European Human Rights Law Review 463(5) (2001), 463-497. 
So, does that mean that law - perhaps not in its inner logic, but rather through the politicisability of legal knowledge - in the end is only politics, as Realists and critical legal scholars tell us? ${ }^{29}$ After all, researching 'politicisation' defined as 'making previously unpolitical matters political' ${ }^{30}$ - in an already highly politicised field of knowledge might seem useless at best. For a theoretical answer, insights from constructivist norm research might help. According to these insides, law is indeed politics, and legal knowledge is always also political knowledge, but not only: Law possesses a certain logic of its own, which eludes too crude manipulation and abuse of law - something, which Lothar Brock has referred to as the intrinsic limits of the political instrumentalisation of law. Following Brock, the essential unavailability (Unverfügbarkeit) of law results from the fact that law can only serve as a political instrument as long as a relevant audience is acknowledging its normative meaning as law: ${ }^{31}$ 'Those who use the language of law submit to the logic of law, because otherwise the reference to law would remain politically ineffective. Every reference to law is therefore an act of self-binding to law.' ${ }^{32}$ Accordingly, despite its highly political nature, law is more than a mere continuation of politics by other means. Instead, the politics of legal knowledge, as I grasp them here, are defined as a scholar's deliberate ignorance, avoidance or selective application of international legal normativity because of extra-legal, i.e. political preferences.

Thus, the critical analysis proposed here aims at deconstructing these deliberate scholars' subordinations of law under politics and the justificatory strategy behind them. For this, I propose a reflexive analysis of historical discourses on war, politics and the histories of international law in the sense of Reinhart Koselleck: As Koselleck described it, writing history scientifically is simply impossible without theory formation on 'possible histories'. It depends on the historian's Standpunkt, his ideological biases. At the same time, however, the scholar's Standpunkt is limited by the fact that historical (and legal)

29 See, e. g., Hurd, Ian. How to Do Things with International Law. A Provocative Reassessment of the Rule of Law in World Politics (Princeton: Princeton University Press, 2017).

30 Zürn, Michael. 'The Politicization of World Politics and its Effects: Eight Propositions'. European Political Science Review 6(1) (2014), 47-71, 5 o.

31 Brock, Lothar. 'Frieden durch Recht. Anmerkungen zum Thema im historischen Kontext', in Frieden durch Recht?, eds. Peter Becker, Reiner Braun and Dieter Deiseroth (Berlin: Berliner Wissenschafts-Verlag, 2010), 15-34. See also Brock/Simon, Selbstbehauptung 2018 (n. 19) and Forst, Rainer. Normativity and Power: Analyzing Social Orders of Justification (Oxford: Oxford University Press, 2017).

32 Brock, Lothar. 'Frieden durch Recht. Zur Verteidigung einer Idee gegen die "harten Tatsachen " der internationalen Politik'. Hessische Stiftung Friedens- und Konfliktforschung Standpunkte 18(3) (2004), 8; Brock, Frieden durch Recht 2010 (n. 31). 
sources have a Vetorecht (veto power). ${ }^{33}$ It describes the possibility of (other) scholars to reject obviously wrong, i.e. untenable historical (or legal) interpretations and theories through source criticism. The task of a critical science of (the politics of) international law could therefore be to recognise the political character of law as well as its essential political unavailability, and to take on a mediating position of law as political and apolitical: In Anne Peters' words, 'scholars might acknowledge that an ambivalence between normative and positive analysis characterises international legal scholarship, and that this ambivalence embodies a tension which can be productive. 34

Even more: In writing histories of international law and its politics, these ambivalences increase, as we are not only confronted with our own standpoints, but also with those of the authors we write about. Nonetheless, reconstructing these Standpunkte developed by lawyers in specific historical contexts may help us to better understand not only the role of legal scholars in the field of tension between objective impartiality and political interests, but also the authority, politicisability and essential political unavailability of law. In order to stimulate such political-sociological perspectives on legal knowledge and modern justifications of war, the next section develops a short genealogy of the formation of (parts of) the modern war discourse and investigates the role of international legal knowledge in this genesis. For this, I turn to 19th-century Europe.

\section{Politics, 19th-Century Legal Scholarship and the Birth of the Modern War Discourse}

Liberal histories of legal progress classically recognise the 19th century war discourses as pre-modern and anarchical, followed by a 'New World Order' in the 2oth century. In The Internationalists, Oona A. Hathaway und Scott J. Shapiro claim that in the 'Old World Order' prior to the legal prohibition of war in 1928, war was 'simply a continuation of politics by other means' - 'might was right'.35 However, as I have argued elsewhere, the widespread positivist thesis of a 'free right to go to war' (liberum ius ad bellum) does not stand up to a closer examination of 19th-century legal theory and political practice; it constitutes a Clausewitzian myth (or fallacy) in the History of International Law. ${ }^{36}$

33 Koselleck, Vergangene Zukunft 2017 (n. 7).

34 Peters, Scholarship 2017 (n. 22), 134.

35 Hathaway/Shapiro, The Internationalists 2017 (n. 5), xv.

36 Simon, Hendrik. 'The Myth of Liberum Ius ad Bellum: Justifying War in 19th-Century Legal Theory and Political Practice'. European Journal of International Law 29(1) (2018), 113-136, doi: 10.1093/ejil/chyoog. I have developed this argument in more detail in Simon, 
In terms of the international normative order governing the use of force, the 19th century was not a century of anarchy. Instead, following the French Revolution(ary Wars), the long 19th century witnessed the birth of the modern discourse of war, normativity and international order. ${ }^{37}$ While there existed no general legal prohibition of war, 'the preservation of the peace of Europe' became a desired norm both in legal theory and political practice. Although wars of aggression (if in different definitions of the term) have been regarded as illegitimate throughout human history, ${ }^{38}$ now - in the 19th century political and theoretical efforts to achieve a positive ius contra bellum were made for the first time.

However, in addition to legalisation, non-legal spheres also kept their discursive power in 19th century war discourses: inter alia morality, politics, social custom, economics, and, to an increasing extent, nationalism. My thesis is therefore that to this day the modern discourse of war is shaped by 'multinormativity'39 and that for lawyers, this normative plurality poses both scientific challenges and political opportunities. Accordingly, the 19th-century legal-political debates on the use of force in the ambivalent interplay between nationalism ${ }^{40}$ and internationalism are closer to the present than usually assumed. This makes it an ideal starting point for reflecting on the politics of legal knowledge and the justification of force in modernity.

\subsection{Revolutionary Mind-Sets: International Legal Scholarship at the Dawn of the 'Long 19th Century'}

When in 1796 German legal scholar Georg Friedrich Martens was commenting on recent developments in international law, he recognised the dialectic liaison between violence and (international) order: The war discourse in Revolutionary France had been radicalised. It challenged the acceptance of shared practices, sources and principles of international law. Nationalism was spreading. Martens through his close connections with the Hanover Electorate was a legal and political representative of the old international order in one

Hendrik. Der Mythos vom "freien Recht zum Krieg". Zu einer Genealogie der modernen Kriegslegitimation (forthcoming).

37 Ibid.

38 Ibid.; Tischer, Herrschaftskommunikation 2012 (n. 3); Lesaffer, Randall. 'Aggression before Versailles'. European Journal of International Law 29(3) (2018), 773-808, doi: 10.1093/ejil/ chyo38. See also the contributions in Brock/Simon, Justification of War 2021 (n. 1).

39 Vec, Multinormativität 2009 (n. 11).

40 Berman, Nathaniel. Passion and Ambivalence: Colonialism, Nationalism, and International Law (Leiden: Martinus Nijhoff, 2012). 
way or another. ${ }^{41}$ To him, the revolution and its natural-law principles seemed to endanger the society of sovereign states. ${ }^{42}$ From Martens' conservative and positivist point of view, the revolutionary thinkers could not be taken seriously. Their natural law principles were developed essentially along concrete conflicts, not in abstract treatises: The justification of violence against the first of seven enemy coalitions (1792-1815) was debated in the French National Assembly. As many delegates were lawyers or philosophers - some of them publishing on politics and law -, political practice and legal/political theory were to some extent interwoven in these debates. Although widely ignored in the History of International Law, ${ }^{43}$ the legal ideas of French Revolutionaries shaped the modern war discourse significantly.

While the revolutionary discourse on the use of force was pacifist in its early phase, this peaceful mantle was quickly thrown off. Now a narrative became central, which would challenge the international order for the entire 19th century: the principle of popular sovereignty. ${ }^{44}$ In April 1792, revolutionaries both scandalised the alleged threat of a military intervention by Austria and Prussia and at the same time justified their 'counter violence' au nom de la Nation. After the Declaration of Pillnitz, the French nation was to be protected from monarchical interference. For this, the doctrine of 'just war' was modified: In 1792 , this meant to justify preventive self-defence.

Particularly interesting for the French legal war discourse is Philippe Antoine Merlin de Douai, un jurist en politique experienced both in legal theory and practice. ${ }^{45}$ In 1790 , he justified an early case of French annexations, the case of Alsace: After having interpreted old international treaty law in favour of France, Merlin de Douai rejected this very treaty law as an 'old language' not to be used anymore. "The law of nations is not founded on the treaties of princes'. Instead, he referred to the 'sovereignty of the people' in Alsace and the

41 Koskenniemi, Martti. 'Into Positivism: Georg Friedrich von Martens (1756-1821) and Modern International Law'. Constellations 15(2) (2008), 189-207.

42 Martens, Georg Friedrich von. Einleitung in das positive Europäische Völkerrecht auf Verträge und Herkommen gegründet (Göttingen: Dieterich, 1796), 297.

43 Lesaffer, Randall. 'In the Embrace of France. An Introduction', in In the Embrace of France: The Law of Nations and Constitutional Law in the French Satellite States of the Revolutionary and Napoleonic Age (1789-1815), eds. Beatrix Jacobs, Raymund Kubben and Randall Lesaffer (Baden-Baden: Nomos, 2008), 7-14, 1, 7-14.

44 Yack, Bernard. 'Popular Sovereignty and Nationalism'. Political Theory 29(4) (2011), 517536; Kolla, Edward J. Sovereignty, International Law, and the French Revolution (Cambridge: Cambridge University Press, 2017).

45 Leuwers, Hervé. Un juriste en politique: Merlin de Douai, 1754-1838 (Arras: Artois Presses Université, 1996). 
will of the Alsatian people to unite with the French. ${ }^{46}$ As Hervé Leuwers and Edward J. Kolla have shown, Merlin de Douai argued as a politicised lawyer, not only in so far, as he adopted the normative language of the French Revolution but also because of the fact that he was willing to propose to the German princes indemnities for Alsace instead of insisting on a consequent, 'objective' application of revolutionary law.

Another important example of the French Revolution's impact on theoretical war discourses is Immanuel Kant as a modern thinker on 'peace through legal progress': From a Königsberger distance, Kant witnessed the unfolding of the revolution with mixed feelings. On the one hand, he hoped for democratisation and legalisation of human relations through the proliferation of reason in open discourse. The telos of his normative project was a republican constitution. Thus, Kant had sympathies for the revolutionary ideas of prohibiting wars of aggression, which seemed to indicate the emergence of a peaceful republic. This meant that Kant was hostile to a forceful spread of the revolution via conquest. ${ }^{47} \mathrm{He}$ neither accepted wars justified by natural law nor by political interests.

On the other hand, however, recent studies argue that Kant was not only enthusiastic about the revolution and indifferent to the execution of King Louis $\mathrm{XVI},{ }^{48}$ but - while denying a right to resistance against a self-determined and liberal legislation - he also assumed a right to resist tyrants and despots acting against the law. ${ }^{49}$ The latter assumption is plausible insofar as Kant tolerated revolutionary violence if it resulted in an adequate constitution. ${ }^{50}$ Kant's idea of law was that it would overcome violence - but at the same time he accepted political violence embedded in legal emancipation. The dialectics of the Enlightenment become plainly apparent here. If even the legal-theoretical thinking of Kant was not entirely free of the politics of his time, it is reasonable to assume that multi-normativity would prevail in 19th century legal thinking on war and peace: With Kant, positive law became the new theology of the

$46 \quad$ Kolla, Sovereignty 2017 (n. 44), 64-66.

47 Kant, Immanuel. Project for a Perpetual Peace: A Philosophical Essay (London: Couchman, 1796).

48 Paula Oliveira, Maria Lúcia de. 'Compatibility of the Moral Foundation of Law in Kant with the Theory of Reflective Judgment and with the Kantian Theory of Revolution', in Kant's Theory of Law, eds. Jean-Christophe Merle and Alexandre Trivisonno (Stuttgart: Franz Steiner Verlag, 2015), 35-44.

49 Pfordten, Dietmar von der. 'Kant on the Right of Resistance', in Kant's Theory of Law, eds. Jean-Christophe Merle and Alexandre Trivisonno (Stuttgart: Franz Steiner Verlag, 2015), 101-119.

$5^{\circ}$ Eberl, Oliver and Peter Niesen. Immanuel Kant. Zum ewigen Frieden und Auszüge aus der Rechtslehre - Kommentare (Frankfurt am Main: Suhrkamp, 2011), 291. 
normative discourse of modernity ${ }^{51}$ - and legal scholars became its priests. However, convinced as they may have been - these priests always had other gods beside them. Nationalism was one of them.

\subsection{The (Dis-)Unity of Law: Nationalism, War and Legal Scholarship in the roth Century}

When the principle of self-determination underpinning the French Revolutionary Wars shook up Europe's international order, the Great Powers aimed at restoring order at the Congress of Vienna. 'Vienna 1814/15' became a 'decisive turning point' of international history:52 From now on, multilateral diplomacy was to guarantee a general European peace between the Great Powers. Political conflicts were to be judged in 'perfect concert'; 53 unilateral warfare beyond the consensus of the Great Powers became inacceptable. Of course, the use of force remained the object of a highly political discourse, but at the same time, legal rules and behavioural norms played an important roleand lawyers became central actors in ordering this discourse. ${ }^{54}$

Perhaps the Concert's central construction error was its mismanagement of social conflicts: The Great Powers nullified the revolutionary legal principle of self-determination. Yet, they could not expel it from the Zeitgeist. ${ }^{55}$ Social conflicts did not simply disappear. As Jürgen Osterhammel has put it: The 19th century may not have been a century of nation states (instead of empires), but it was a century of nationalism as an emerging political mythology. ${ }^{56}$ Nationalism both delegitimised the existing legal order of empires and promoted an international order based on the nation state. ${ }^{57}$ This becomes apparent in the fact that war was the first instrument of choice for achieving nationalist unification as in the German Unification Wars and the Italian

51 Habermas, Jürgen. The Philosophical Discourse of Modernity: Twelve Lectures (Cambridge: Massachusetts Institute of Technology Press, 1990).

52 Schroeder, Paul W. The Transformation of European Politics. 1763-1848 (Oxford: Oxford University Press, 1994), vii.

53 Schulz, Matthias. Normen und Praxis. Das Europäische Konzert der Großmächte als Sicherheitsrat, 1815-1860 (Berlin: De Gruyter, 2009), 4.

54 Simon, Myth 2018 (n. 36); Payk, Frieden durch Recht? 2018 (n. 3).

55 Fisch, Jörg. A History of the Self-Determination of Peoples: The Domestication of an Illusion (Cambridge: Cambridge University Press, 2015), 105.

56 Osterhammel, Jürgen. The Transformation of the World: A Global History of the Nineteenth Century (Princeton: Princeton University Press, 2014).

57 Summers, James. Peoples and International Law: How Nationalism and Self-Determination Shape a Contemporary Law of Nations (Leiden: Martinus Nijhoff, 2007). 
Risorgimento, and that nationalism finally devastated the European Concert in the Great War.

Starting from this contribution's core thesis that legal scholarship is open to politicisation, it comes as no surprise that especially in the German and Italian territories legal doctrines referred to the principles of self-determination and nationalism. An important theoretical source was Friedrich Carl von Savigny's historical school of law and its 'supranational historicism. ${ }^{58}$ Savigny, a German conservative and cosmopolitan lawyer, believed in the lawyer's task to reflect on the legal conscience' of a national culture (Volksgeist). ${ }^{59}$ Accordingly, Völker should become the prime actors in international law.

This historical school was influential particularly among 19th-century liberal nationalist legal scholars like Mancini, Bluntschli or Lieber. ${ }^{60}$ While Savigny himself was sceptical about German nationalism at his time, his followers more and more reconciled liberalism and (moderate) nationalism. This liaison between liberalism and nationalism seems contradictory from a later point of view and the collective memory of two World Wars. Already in 1910, Westlake would warn that nationalities, 'though often important in politics, must be kept outside of international law' 61 Yet the liaison was logically plausible in the mid-19th century as multinational empires were at the time the most illiberal states and nationalism could be seen as an emancipatory mission. ${ }^{62}$

Accordingly, the appeal that European 'civilised' peoples had the right to unite had an anti-imperial impetus. The Italian Pasquale Stanislao Mancini referred to the French Revolution and argued in favour of peoples' moral and legal right to unite in a state. ${ }^{63}$ In fact, liberal lawyers usually did not understand nationalism and internationalism as contradicting, but as consecutive principles. But the lawyers' 'reflexive relationship' with the Volk, ${ }^{64}$ as Savigny had described it, also made liberal lawyers become more and more committed to national, and, with this, to political projects. From now on, it made a political difference whether someone was a German, French or Russian international lawyer.

$5^{8}$ Koskenniemi, Martti. The Gentle Civilizer of Nations: The Rise and Fall of International Law, 1870-1960 (Cambridge: Cambridge University Press, 2002), 45; Shahabuddin, Mohammad. Ethnicity and International Law. Histories, Politics and Practices (Cambridge: Cambridge University Press, 2016), 53.

59 Koskenniemi, Gentle Civilizer 2002 (n. 58), 45.

6o Summers, Peoples and International Law 2007 (n. 57), 112.

61 Ibid., 157 .

62 Ibid.

63 Kolla, Sovereignty 2017 (n. 44), 294.

64 Koskenniemi, Gentle Civilizer 2002 (n. 58), 43. 
Furthermore, liberal scholars began to accept political violence as a means of legal progress. With this, Kelsen's boundaries between law and politics became blurred. Particularly revealing are the writings of German (speaking) liberal lawyers in the context of the German Wars of Unification. An important example is Swiss lawyer Johann Caspar Bluntschli, professor in Heidelberg and later one of the founding members of the Institut de Droit International: Bluntschli wrote in Kant's legal pacifist tradition. Accordingly, he strove for a complete legalisation of war in the sense of a positive ius contra bellum. Bluntschli became a main opponent of those German legal scholars who would recognise war as a Clausewitzian political instrument. ${ }^{65} \mathrm{~A}$ war for political reasons was to be rejected, wrote Bluntschli: 'The mere interest of the state in itself does not justify war. ${ }^{6} 6$ In this respect, he perfectly corresponded to Kelsen's ideal type of a legal scholar advocating the de-politicisation of law.

However, Bluntschli not only sympathised with Bismarck's unification policy from a scholarly distance, he also justified it as a member of the Baden Parliament. In this respect, he corresponded to Kelsen's real type of a politicisable legal scholar. Even if Bluntschli rejected Rousseau's Contrat Social as the basis of state theory, the analogy of his justification of Prussia's wars to those of French revolutionary legal scholar Merlin de Douai is astonishing: Bluntschli wrote of the 'holy, natural and important right' of a Volk as a political community. The necessity of a contemporary reorganisation of the state was to be recognised and carried out. At the same time, the existence of the historically evolved law had to be protected as long as it was viable and contemporary, argued Bluntschli. ${ }^{67}$ Obviously, however, this also meant that positive law should not be regarded as sacrosanct. Rather, the Concert's norms of restraint were to be abandoned when they proved to be out of date. According to Bluntschli, contesting emerging law (werdendes Recht) meant disregarding the 'vital nature of right' (lebendige Natur des Rechts) and, thus, the further development of law as a means of 'self-fulfilment of peoples' (Entwicklung der Völker). In this understanding of law as a living body, Savigny's impact on Bluntschli's thinking becomes clear.

But Bluntschli also left Savigny clearly behind, as he was referring to nationalism and self-determination as narratives for the justification of the German Wars of Unification. This is remarkable: It is clear not only to subsequent

65 Lueder, Karl. 'Krieg und Kriegsrecht im Allgemeinen', in Handbuch des Völkerrechts, ed. Franz von Holtzendorff (Berlin: Haber, 1889), 169-397, 169, 180-184. See also Simon, Myth 2018 (n. 36).

66 Bluntschli, Johann Caspar. Das moderne Völkerrecht der civilisirten Staten: als Rechtsbuch dargestellt (Nördlingen: C.H. Beck, 1868), 290-291.

67 Ibid. 
historians, but it was also recognised by some contemporaries that Bismarck had planned the wars for a considerable time and unleashed them for purely political reasons - even though Bismarck tried to bring his policies into line with the norms of the European Concert. Bismarck tried to justify the war against France as a defensive war ${ }^{68}$ when Bismarck's Realpolitik had already become obvious in the war of 1866, which had begun without a declaration of war.

Nevertheless, Bluntschli followed Bismarck in declaring the Franco-Prussian War as a defensive war. ${ }^{69}$ Furthermore, Bluntschli described Bismarck as one of the two most brilliant statesmen in German history - alongside Frederic the Great. What a curious admiration of a liberal lawyer for two of the most explicit representatives of Prussian Realpolitik! Bluntschli justified the violent integration of Schleswig and Holstein into the German Confederation (1864) as well as the 1866 war against Austria as an emancipatory act of a German nation that 'defends its right and honour' (seine Ehre zu wahren, und daher sein Recht). ${ }^{70}$

Bluntschli's justification was clearly based on an understanding of nations as catalysts for legal progress. While for Bluntschli a state did not have to be ethnically homogeneous, it had to have a certain status of power and 'civilization. ${ }^{71}$ As a cosmopolitan, Bluntschli sought to reconcile law, nationalism and liberalism. In this context, violence was acceptable for the liberal cosmopolitan - if it served the right national purpose. With this, the analogies in Bluntschli's and Merlin de Douai's thinking become clear: Both delegitimised 'old', dynastic international law in favour of a nation's unity derived from natural law. According to Bluntschli, people had the right 'to take the state-form necessary to develop its natural capacity, to fulfil its destiny, to ensure its security and to preserve its honour, and therefore the right to resort to arms if necessary.' In his view, this was 'a much more sacred, natural and important right than any dynastic law'72 Like Merlin de Douai in 179o, Bluntschli advocated progress de lege ferenda, based on natural law, nationalism and political convictions. As becomes evident here, multi-normativity was still alive in the war discourse of the so-called 'positivist century'. ${ }^{3}$

68 Simon, Myth 2018 (n. 36).

69 Bluntschli, Johann Caspar. Das moderne Völkerrecht in dem Kriege 1870: Rede zum Geburtsfeste des höchstseligen Grossherzogs KarlFriedrich von Baden und zur akademischen Preisvertheilung am 22. November 1870 (Heidelberg: Mohr, 1870).

$70 \quad$ Bluntschli, Das moderne Völkerrecht 1868 (n. 66), 291.

71 Bluntschli, Johann Caspar. The Theory of the State (Kitchener: Batoche Books, 1875), 94.

72 Bluntschli, Das moderne Völkerrecht 1868 (n. 66), 291.

73 Vec, Miloš. 'Sources in the 19th Century European Tradition: The Myth of Positivism', in The Oxford Handbook of the Sources of International Law, eds. Samantha Besson and Jean d'Aspremont (Oxford: Oxford University Press, 2017), 121-145. 
Similarly - but from a different legal-theoretical perspective - liberal lawyer Rudolf von Jhering expressed sympathy for the German unification in private correspondences. ${ }^{74}$ What is remarkable here is Rudolf von Jhering's inner conflict emerging from the tension between law, morality and his political sympathy for Prussian nationalism, as expressed in a letter to Austrian lawyer Julius Glaser of 1 May 1866: Jhering, who described himself in the letter as an opponent of the Austrian political system - 'but not of the Austrians' -, wrote that perhaps no war had ever been started with a 'shamelessness' (Schamlosigkeit), 'a horrible frivolity' (grauenhaften Frivolität), as the one Bismarck was trying to drum up against Austria at that time. Jhering was outraged at such 'an offence against all the principles of law and morality'. However, he felt a contradiction between law and politics in himself: His sense of law (Rechtsgefühl) and his political interests had come into 'a tragic conflict', as he reported to Glaser. From a legal perspective, Jhering felt the duty to wish Austria luck in war. However, for political reasons, he felt the need to wish the 'unjust cause' - Prussia's victory - success in the battlefield.

Obviously, there were two hearts pounding in Jhering's chest, one political and one legal: Finally, Jhering's political heart was to beat faster, as he informed Leipzig legal scholar Bernhard Joseph Hubert Windscheid in a letter of 15 June 1866:75 He bowed to the genius of Bismarck, who had 'delivered a political masterpiece'. And Jhering even mocked the powerless honesty and scientific objectivity of legal scholars: Full of national pride, Jhering concluded, for a political genius like Bismarck, he would give a hundred of liberals of powerless honesty. What a triumph of politics over law! Of course, these were private correspondences, not scientific treatises. And it is also true that Jhering was very open and reflective about his initial discomfort with his own euphoria about Prussia's wars. Nevertheless, Jhering weighed between law and politics, and made a clear decision: Politics was it.

The arguments of Jhering and Bluntschli - two of the most important German liberal lawyers at their times - demonstrate that Kelsen would be right in his concern that legal scholars could become the mouthpiece of nationalist power politics. The devastating potentials of nationalism as a source of war justification became even clearer at the end of the century. As I have shown elsewhere, ${ }^{76}$ the unification of Germany - praised by liberal legal

74 Quoted according to Faber, Karl-Georg. 'Realpolitik als Ideologie. Die Bedeutung des Jahres 1866 für das politische Denken in Deutschland'. Historische Zeitschrift 203(1) (1966), $1-45$.

75 Ibid.

$7^{6}$ Simon, Myth 2018 (n. 36). 
scholars - enabled the development of a German legal doctrine oriented towards a Clausewitzian understanding of war, which placed Realpolitik above the need to contain war. This became obvious in German justifications of violence in the contexts of the Herero and Nama Genocide and the First World War. ${ }^{77}$ Of course, in the latter, lawyers of all nations succumbed to nationalism. But particularly in German political and legal discourse, militarism and nationalism had now at last outdone liberalism - politics had won over law, Clausewitz over Kant.

\subsection{Inventing Intervention, Circumventing Law: Another Normative Telos of Modernity}

The prime instrument of the European Great Powers to counter emerging nationalism was military intervention. What distinguished it from war was that a military intervention should not be conducted in the name of unilateral interests, but in the name of the 'international community' ${ }^{78}$ Interventions thus were to enforce the norms of the Concert. In view of its highly political character, however, intervention was also repeatedly a test for Concert diplomacy. Particularly in legal doctrine, intervention became one of the most debated issues of the 19th century. ${ }^{79}$ It was poorly regulated not to stand in the way of the Concert's interests: The vocabulary of positive law was not to become a language barrier for politics.

In the course of the 19th century, a new type of intervention emerged as part of dealing with the Oriental Question: 'humanitarian intervention.80 According to Russian lawyer Fedor Fedorovich Martens, a military intervention was justifiable following the 'commonality of religious interests and the commandments of humanity, that is the principles of natural law'. The Eurocentric focus of intervention came to light when Martens added that an

77 Hull, Isabel V. Absolute Destruction. Military Culture and the Practices of War in Imperial Germany (Ithaca: Cornell University Press, 2005); Hull, Isabel V. A Scrap of Paper: Breaking and Making International Law during the Great War (Ithaca: Cornell University Press, 2014).

78 Schulz, Normen und Praxis 2009 (n. 53).

79 Vec, Miloš. 'Intervention / Nichtintervention, Verrechtlichung der Politik und Politisierung des Völkerrechts im 19. Jahrhundert', in Macht und Recht. Völkerrecht in den internationalen Beziehungen, eds. Ulrich Lappenküper and Reiner Marcowitz (Paderborn: Schöningh, 2010), 135-16o.

$80 \quad$ Rougier, Antoine. 'La théorie de l'intervention d'humanité. Revue génerale de droit international public 17 (1910), 468-526. 
intervention was explicitly legitimate 'in Turkey, China, Japan and other Asian states' if the Christian population was subjected to persecution or 'slaughter'. 81

In the debates on 'humanitarian interventions', international lawyers played a central role, as can be illustrated with a view to the Russo-Turkish War of 1877/78: With the Crimean War of $1853^{-56}$, the Oriental Question had interrupted, but not destroyed the Vienna Peace Order. The defeat of the Russians against the alliance of the Ottoman Empire, England, France and PiedmontSardinia was clearly expressed in the Peace Treaty of 1856 . Article 9 of the treaty prohibited intervention in the territory of the Ottoman Empire; this was backed by the assurance on the part of the Ottoman Sultan to improve the situation of the Christian population in the Balkan regions. Article 7 formally granted the Ottoman Empire participation in the European community of international law and in the Concert of the Great Powers, although it did not de facto grant it the status of a European Great Power. These provisions of the Treaty of Paris amounted to a regional ban on intervention which was clearly directed against Russian war policies. According to the peace treaty, positive international law denied Russia the right to intervene into what was to be considered as the internal affairs of the Ottoman Empire. Nevertheless, on 24 April 1877, Russian Tsar Alexander II declared war on the Sublime Porte after Turkish armed forces had suppressed uprisings in their Balkan areas in the spring of 1876 using extensive force and killing numerous civilians in the so-called Bulgarian Horrors.

It is not surprising that the legal ban on intervention formulated in the treaty as positive law was invoked as a normative obstacle to the justification of the Russian use of force. Russian Foreign Minister Alexander Gorchakov summed up the Russian denial of the norm by claiming that 'the European action in Turkey has been reduced to impotency by the stipulations of $1856^{\prime},{ }^{82}$ According to Gorchakov, Turkey's independence had to be subordinated to 'interests of humanity, the Christian community and general peace'. ${ }^{83}$ Russia was successful with its strategy to invalidate Article 9 of the Peace of 1856 after the victorious war against the Ottomans: In the Berlin Treaty of 1878, the norm of non-intervention into the internal affairs of the Ottoman Empire was abandoned. This was the political side of the matter.

81 Martens, Friedrich von. Völkerrecht. Das internationale Recht der civilisirten Nationen (Berlin: Weidmann, 1883), 302.

82 Gortschakow, 19th November 1876, in The Map of Europe by Treaty. Showing the Various Political and Territorial Changes which Have Taken Place since the General Peace of 1814. With Numerous Maps and Notes, vol. 4: 1875-1891, ed. Edward Hertslet (London: Butterworths, 1891), 2523 .

83 Gortschakow, 19th November 1877, in Hertslet, Map of Europe 1891 (n. 82), 2524. 
As to the academic side, Fedor Fedorovich Martens, law professor and diplomat in St. Petersburg, was entrusted with the task of investigating Russian politics scientifically - or, rather, with justifying it? Martens' dual professional role ${ }^{84}$ is particularly interesting here: On the one hand, he was a legal scholar highly respected throughout Europe. On the other hand, Martens was crown jurist of the Russian Tsar as well as diplomat of the Russian Foreign Ministry. Thus, he was recognised as 'the most legal-minded of diplomats and the most expert diplomat among lawyers'. ${ }^{85}$ In a 46-page 'historical study' published in West and Central European journals in 1877, Martens examined the Russian 'intervention' in the Ottoman Empire. In his study, Martens argued that the protection of Christians in Turkey was a pan-European responsibility. However, since the Great Powers were disunited, Russia had a 'moral and legal right to intervene in Turkey's internal affairs'. ${ }^{66}$ With this argument, Martens attempted to disguise Russia's political interests in the Balkans by referring to the humanitarian task of the international community.

Like Gorchakov, Martens referred in particular to Article 9 of the 1856 peace treaty and the Sultan's voluntary concessions therein to improve the lot of the Christian population: According to Martens, Russia had only signed the treaty in 1856 because the European Concert had assumed the right of collective intervention in Russia's place. Thus, in Martens' view the Treaty of Paris had neither left Christians to 'Muslim fanaticism' nor abolished 'Europe's right to intervene. ${ }^{87}$ If Europe did not exert its right, the powers particularly involved in the Oriental question were free to intervene - the article could not be interpreted differently, Martens argued. ${ }^{88}$ Martens constructed a Russian right and obligation to intervene in the Ottoman Empire, for which he combined historical law - in particular the Treaty of Kütschük-Kainardschi of 1774 - and religious rights of Christians.

What is striking, however, is that Martens did not fully discuss Article 9 of the Treaty of Paris in his essay. He simply ignored its ban of interventions. Moreover, a comparison of Martens' argumentation in his 'historical study' and his scientific textbook on international law of 1883 reveals an interesting

84 Mälksoo, Lauri. 'F. F. Martens and His Time: When Russia Was an Integral Part of the European Tradition of International Law'. European Journal of International Law 25(3) (2014), 811-829.

85 Eyffinger, Arthur. The 1907 Hague Peace Conference: 'The Conscience of the Civilized World' (The Hague: Judicap, 2007), 29.

86 Martens, Friedrich von. Die russische Politik in der Orientalischen Frage. Eine historische Studie (St. Petersburg: H. Schmitzdorff, 1877), 45 et seq. (italics in the original).

87 Ibid., 19 .

88 Ibid., 15 . 
self-contradiction: In 1877 , Martens denied the fact that the treaty of 1856 had established a legal prohibition of unilateral intervention into the Ottoman Empire. In the second volume of his 1883 textbook, however, Martens criticised the 1856 treaty precisely for having abolished the right both of collective and unilateral intervention. ${ }^{89}$ This criticism presupposes, of course, that Martens recognised the non-intervention norm set out in 1856 as legally binding. Even Martens' observation that Europe had turned to illegal politics of intervention in the Orient before with the French occupation of Syria in 186o, on closer examination turns into an argument against his own reasoning: The intervention of 1860 was preceded by negotiations between the Great Powers and the Ottoman Empire, in which - as Martens himself admitted - the Ottoman Empire agreed to an intervention..$^{90}$ Moreover, the accusation that Europe had broken the non-intervention norm of 1856 in 1860 seems downright absurd in view of the fact that Martens himself ignored this prohibition of military intervention in his study of 1877 .

In any case, Martens' remarks were incompatible with the positive law of the normative sub-order of 1856 . Martens simply became an apologist of Alexander's II politics of war: In his argumentation, international law and politics are inseparable. Martens' study can be understood as a justification for the offensive Russian policy towards the Orient. Instead of a legal scientific study of positive law, Martens presented a political treatise. Martens even opposed the attempt of other members of the Institut de Droit to publicly protest Russian excesses of violence and its violations of positive law during the campaign - ironically, he did so in the name of 'scientific neutrality'. ${ }^{91}$ Even though, from a methodological perspective, Martens' argumentation is highly interesting: He mixed alleged historical law (customs) and natural law in order to delegitimise the treaty law of 1856 . At the same time, the new positive legal norm of 1878 was scientifically fleshed out with reference to natural law and historical customs of civilised states.

Martens' claim that his study was not 'to influence the judgment of our readers' ${ }^{\prime 22}$ seems hardly credible - for the true intentions of Martens' study were revealed in the introduction to the German translation in the Russische Revue: Accordingly, the aim of the publication was 'to eliminate the still widespread misconceptions about Russia's oriental politics and its goals in the Orient. ${ }^{93}$ In

89 Martens, Völkerrecht 1883 (n. 81), 127.

$90 \quad$ Martens, Russische Politik 1877 (n. 86), 21.

91 Koskenniemi, International Law in Europe 2005 (n. 25), 124.

92 Martens, Russische Politik 1877 (n. 86), 2.

93 Ibid., 1. 
fact, politics had triumphed over scholarly 'objectivity' here. Again, natural law had become the most important instrument to enforce political goals and to circumvent positive law. In the 19th century, it remained a substitute religion for the priests of positive law. Knowledge in the Modern War Discourse

The starting point of this chapter was a distinction between 'objective' and 'political' scholars developed based on some of Hans Kelsen's works. The politicisability of legal scholars was first discussed at a theoretical level and then illustrated by analysing discursive fragments from the modern discourse of war and international order in its epoch of birth, the 'long 19th century'. This was done without any claim to provide the last word on the issue, but rather to (re-)open this exciting field of research by demonstrating the fuzziness of the borderlines between legal and political discourse. Of course, I could only address individual examples as 'illustrations' of the politicisability of international legal scholars here; however, these illustrations refer to lawyers/ legal thinkers who were particularly respected in their times.

Thus, what can be concluded here is quite remarkable: Firstly, all legal scholars examined in this chapter were politicisable in the sense of Hans Kelsen's real type. Some of them confessed their political projects, if with a certain uneasiness: During the German Wars of Unification, Jhering felt both a legal and a political heart beating in his chest. In contrast, Fedor Fedorovich Martens tried to disguise his political objectives by claiming 'scientific objectivity'. The misuse of the latter helped to suppress the intrinsic value of law and even to marginalise scientific opponents in the name of scientific neutrality just as Kelsen would criticise.

Secondly, there is an astonishing similarity in the justification strategies of the legal scholars examined: Merlin de Douai, Bluntschli, Jhering and Martens all justified breaches of positive law in accord with their political programs by pointing to a plurality of normative arguments, be it natural law, nationalism, self-determination, custom, honour, or even openly formulated political interests. Furthermore, lege ferenda was played out against lege lata. As can be clearly observed here, the modern war discourse, which emerged in the socalled 'positivist 19th century', ${ }^{4}$ is characterised by multi-normativity. This has considerable effects on legal scholarship and its politicisability.

Critically on this term Vec, Sources 2017 (n. 73). 
In order to return to the starting point of this symposium: What do these paradoxes tell us about the relationship between law and politics? Firstly, that law is politically contested, ${ }^{95}$ and that legal scholars are political actors in the struggle for law (Jhering). Lawyers are not only affected by the shadow of war, it is also lawyers who turn this shadow into a smokescreen. Secondly, it is worth looking twice at who is speaking in legal discourse, from which Standpunkt and with what arguments, and how law is dealt with as a political instrument and as a politically unavailable phenomenon. ${ }^{96}$ Deconstructing the frequent political projects behind legal knowledge helps us to better grasp the fateful liaison between violence, politics and law. ${ }^{97}$

Thus, a broader comparison of historical case studies in the sense of a political sociology of international legal knowledge in the field of justifying force could provide us with patterns about when and why scholars throughout modernity were susceptible to politicisation (or not). Perhaps it could even help us to answer the question whether we are 'better off than those colleagues who set up the profession of international law' 147 years ago' 98 - insofar as the reference to expanding positive law and particularly the legal prohibition of force in Art. 2 (4) UN Charter might enable 'us' to oppose arbitrary politicisation of legal knowledge more effectively and in the sense of Koselleck's Vetorecht. ${ }^{99}$

But then again, would not this reference to positivism be politically motivated itself, as Lassa Oppenheim admitted? So, are we moving in circles in our attempt to do justice to Kelsen's ideal of an apolitical researcher - and should we possibly abandon this ideal altogether? Or is it worth bearing this ambivalence of science and politics - and if so, for whom?

Part of my argument in this chapter with its focus on the 19th century was that narratives of progress or the impossibility of progress in the face of eternal anarchy are always deceptive. As could only be indicated here, in light of the fact that the 19th century is not an anarchic mirror-image of the modern

95 For the concept of 'contestation' in the Theory of International Relations, see Wiener, Antje. Contestation and Constitution of Norms in Global International Relations (Cambridge: Cambridge University Press, 2018).

96 Brock, Frieden durch Recht 2010 (n. 31).

97 Benjamin, Critique 1978 (n. 19); Foucault, L'archéologie 1969 (n. 10); Brock/Simon, Selbstbehauptung 2018 (n. 19).

98 Koskenniemi, International Law in Europe 2005 (n. 25),

99 Critically on this issue Peevers, Charlotte. The Politics of Justifying Force. The Suez Crisis, the Iraq War, and International Law (Oxford: Oxford University Press, 2013); see also Marauhn, Thilo. 'How Many Deaths Can Art 2 (4) UN Charter Die?', in The Justification of War and International Order. From Past to Present, eds. Lothar Brock and Hendrik Simon (Oxford: Oxford University Press, 2021). 
discourse of war and international order, but rather marks its beginning, ${ }^{100}$ the 'radical' plans to outlaw war ${ }^{101}$ of 1920, 1928 or 1945 appear much less radical seen from a perspective of longue durée. ${ }^{102}$ Thus, the cases described here are more than anecdotes - in their logic of justification of war they appear as part of our present. Nationalism and multi-normativity are still with us. A glance at more recent scholarly justifications of the use of force - regarding the NATOintervention in Kosovo (1999), the Iraq War (2003) or the Russian annexation of the Crimea (2014) - seems to confirm Kelsen's concern: Legal scholars can always be the mouthpieces of the powerful - and thus not only gentle civilisers, but at the same time gentle justifiers of violence.

\section{Acknowledgments}

I am grateful to Lothar Brock, Anthony Carty, Anne Peters, Miloš Vec and the anonymous reviewers for helpful comments and advice. A first draft of this text was presented at the stimulating JHIL-symposium on 'Politics and the Histories of International Law' in Heidelberg on 15 February 2019.

\section{Bibliography}

Benjamin, Walter. 'Critique of Violence', in Walter Benjamin, Reflections: Essays, Aphorisms, Autobiographical Writings, ed. Peter Demetz (Boston: Harcourt, 1978).

Benton, Lauren. 'Beyond Anachronism: Histories of International Law and Global Legal Politics'. Journal of the History of International Law 21(1) (2019), 7-40, doi .org/10.1163/15718050-12340100.

Berman, Nathaniel. Passion and Ambivalence: Colonialism, Nationalism, and International Law (Leiden: Martinus Nijhoff, 2012).

Bernstorff, Jochen von. 'International Legal Scholarship as a Cooling Medium in International Law and Politics'. European Journal of International Law 25(4) (2014), 977-99o, doi.org/10.1093/ejil/chuo73.

Bluntschli, Johann Caspar. Das moderne Völkerrecht der civilisirten Staten: als Rechtsbuch dargestellt (Nördlingen: C. H. Beck, 1868).

\footnotetext{
100 Simon, Myth 2018 (n. 36).

101 Hathaway/Shapiro, The Internationalists 2017 (n. 5).

102 For such a perspective of longue durée see Brock/Simon, Justification of War 2021 (n. 1).
} 
Bluntschli, Johann Caspar. Das moderne Völkerrecht in dem Kriege 1870: Rede zum Geburtsfeste des höchstseligen Grossherzogs Karl Friedrich von Baden und zur akademischen Preisvertheilung am 22. November 1870 (Heidelberg: Mohr, 1870).

Bluntschli, Johann Caspar. The Theory of the State (Kitchener: Batoche Books, 1875).

Brock, Lothar. 'Frieden durch Recht. Zur Verteidigung einer Idee gegen "die harten Tatsachen“ der internationalen Politik'. Hessische Stiftung Friedens- und Konfliktforschung Standpunkte 18(3) (2004).

Brock, Lothar. 'Frieden durch Recht. Anmerkungen zum Thema im historischen Kontext', in Frieden durch Recht?, eds. Peter Becker, Reiner Braun and Dieter Deiseroth (Berlin: Berliner Wissenschafts-Verlag, 2010), 15-34.

Brock, Lothar and Hendrik Simon. 'Die Selbstbehauptung und Selbstgefährdung des Friedens als Herrschaft des Rechts'. Politische Vierteljahresschrift 59(2) (2018), 269-291.

Brock, Lothar and Hendrik Simon, eds. The Justification of War and International Order. From Past to Present (Oxford: Oxford University Press, 2021).

Carty, Anthony. 'Critical International Law: Recent Trends in the Theory of International Law'. European Journal of International Law 2(1) (1991), 1-27.

Carty, Anthony. 'Doctrine versus State Practice', in Oxford Handbook of the History of International Law, eds. Bardo Fassbender and Anne Peters (Oxford: Oxford University Press, 2012), 972-996.

Duve, Thomas. 'Was ist "Multinormativität"? - Einführende Bemerkungen'. Rechtsgeschichte - Legal History 25 (2017), 88-101.

Eberl, Oliver and Peter Niesen. Immanuel Kant. Zum ewigen Frieden und Auszüge aus der Rechtslehre - Kommentare (Frankfurt am Main: Suhrkamp, 2011).

Eyffinger, Arthur. The 1907 Hague Peace Conference: 'The Conscience of the Civilized World' (The Hague: Judicap, 2007).

Faber, Karl-Georg. 'Realpolitik als Ideologie. Die Bedeutung des Jahres 1866 für das politische Denken in Deutschland'. Historische Zeitschrift 2O3(1) (1966), 1-45.

Fisch, Jörg. A History of the Self-Determination of Peoples: The Domestication of an Illusion (Cambridge: Cambridge University Press, 2015).

Forst, Rainer. Normativity and Power: Analyzing Social Orders of Justification (Oxford: Oxford University Press, 2017).

Foucault, Michel. L'archéologie du savoir (Paris: Gallimard, 1969).

García-Salmones Rovira, Mónica. The Project of Positivism in International Law (Oxford: Oxford University Press, 2013).

Habermas, Jürgen. The Philosophical Discourse of Modernity: Twelve Lectures (Cambridge: Massachusetts Institute of Technology Press, 199o).

Hathaway, Oona A. and Scott Shapiro. The Internationalists: How a Radical Plan to Outlaw War Remade the World (New York: Simon \& Schuster, 2017). 
Hertslet, Edward, ed. The Map of Europe by Treaty. Showing the Various Political and Territorial Changes which Have Taken Place since the General Peace of 1814. With Numerous Maps and Notes, vol. 4 (London: Butterworths, 1891).

Horkheimer, Max. Traditionelle und kritische Theorie: Fünf Aufsätze (Frankfurt am Main: Fischer, 1992).

Hull, Isabel V. Absolute Destruction. Military Culture and the Practices of War in Imperial Germany (Ithaca: Cornell University Press, 2005).

Hull, Isabel V. A Scrap of Paper: Breaking and Making International Law during the Great War (Ithaca: Cornell University Press, 2014).

Hurd, Ian. How to Do Things with International Law. A Provocative Reassessment of the Rule of Law in World Politics (Princeton: Princeton University Press, 2017).

Janssen, Wilhelm. Die Anfänge des modernen Völkerrechts und der neuzeitlichen Diplomatie: Ein Forschungsbericht (Stuttgart: Metzler, 1965).

Kant, Immanuel. Project for a Perpetual Peace: A Philosophical Essay (London: Couchman, 1796).

Kelsen, Hans. 'Juristischer Formalismus und Reine Rechtslehre'. Juristische Wochenschrift $5^{8}(3)$ (1929), 1723-1726.

Kelsen, Hans. Peace through Law (Chapel Hill: The University of North Carolina Press, 1944).

Kelsen, Hans. 'Science and Politics'. The American Political Science Review 45(3) (1951), 641-661.

Kennedy, David W. 'The Politics of the Invisible College: International Governance and the Politics of Expertise'. European Human Rights Law Review 463(5) (2001), 463-497.

Kingsbury, Benedict. 'Legal Positivism as Normative Politics: International Society, Balance of Power and Lassa Oppenheim's Positive International Law'. European Journal of International Law 13(2) (2002), 401-436.

Kleingeld, Pauline. 'What do the Virtuous Hope for? Re-reading Kant's Doctrine of the Highest Good', in Proceedings of the Eighth International Kant Congress: Memphis, 1995, eds. Hoke Robinson (Milwaukee: Marquette University Press, 1995).

Kolla, Edward J. Sovereignty, International Law, and the French Revolution (Cambridge: Cambridge University Press, 2017).

Koselleck, Reinhart. Vergangene Zukunft:ZurSemantikgeschichtlicher Zeiten (Frankfurt am Main: Suhrkamp, 1oth ed. 2017).

Koskenniemi, Martti. The Gentle Civilizer of Nations: The Rise and Fall of International Law, 1870-1960 (Cambridge: Cambridge University Press, 2002).

Koskenniemi, Martti. 'International Law in Europe: Between Tradition and Renewal'. European Journal of International Law 16(1) (2005), 113-124.

Koskenniemi, Martti. 'Into Positivism: Georg Friedrich von Martens (1756-1821) and Modern International Law'. Constellations 15(2) (2008), 189-207. 
Koskenniemi, Martti. 'What is Critical Research in International Law? Celebrating Structuralism'. Leiden Journal of International Law 29(3) (2016), 727-735.

Leuwers, Hervé. Unjuriste en politique: Merlin de Douai, 1754-1838 (Arras: Artois Presses Université, 1996).

Lesaffer, Randall. 'In the Embrace of France. An Introduction', in In the Embrace of France: The Law of Nations and Constitutional Law in the French Satellite States of the Revolutionary and Napoleonic Age (1789-1815), eds. Beatrix Jacobs, Raymund Kubben and Randall Lesaffer (Baden-Baden: Nomos, 2008), 7-14.

Lesaffer, Randall. 'Aggression before Versailles'. European Journal of International Law 29(3) (2018), 773-808, doi: 10.1093/ejil/chyo38

Lueder, Karl. 'Krieg und Kriegsrecht im Allgemeinen', in Handbuch des Völkerrechts, ed. Franz von Holtzendorff (Berlin: Haber, 1889), 169-397.

Mälksoo, Lauri. 'F. F. Martens and His Time: When Russia Was an Integral Part of the European Tradition of International Law'. European Journal of International Law 25(3) (2014), 811-829.

Marauhn, Thilo. 'How Many Deaths Can Art 2 (4) UN Charter Die?', in The Justification of War and International Order. From Past to Present, eds. Lothar Brock and Hendrik Simon (Oxford: Oxford University Press, 2021).

Martens, Friedrich von. Die russische Politik in der Orientalischen Frage. Eine historische Studie (St. Petersburg: H. Schmitzdorff, 1877).

Martens, Friedrich von. Völkerrecht. Das internationale Recht der civilisirten Nationen (Berlin: Weidmann, 1883).

Martens, Georg Friedrich von. Einleitung in das positive Europäische Völkerrecht auf Verträge und Herkommen gegründet (Göttingen: Dieterich, 1796).

Neff, Stephen C. War and the Law of Nations: A General History (Cambridge: Cambridge University Press, 2005).

Oppenheim, Lassa. 'The Science of International Law: Its Tasks and Method'. American Journal of International Law 2(2) (1908), 313-356.

Orford, Anne and Florian Hoffmann, eds. The Oxford Handbook of the Theory of International Law (Oxford: Oxford University Press, 2016).

Osterhammel, Jürgen. The Transformation of the World: A Global History of the Nineteenth Century (Princeton: Princeton University Press, 2014).

Paula Oliveira, Maria Lúcia de. 'Compatibility of the Moral Foundation of Law in Kant with the Theory of Reflective Judgment and with the Kantian Theory of Revolution', in Kant's Theory of Law, eds. Jean-Christophe Merle and Alexandre Trivisonno (Stuttgart: Franz Steiner Verlag, 2015), 35-44.

Payk, Marcus M. Frieden durch Recht? Der Aufstieg des modernen Völkerrechts und der Friedensschluss nach dem Ersten Weltkrieg (Berlin: De Gruyter, 2018).

Peevers, Charlotte. The Politics of Justifying Force. The Suez Crisis, the Iraq War, and International Law (Oxford: Oxford University Press, 2013). 
Peters, Anne. 'International Legal Scholarship under Challenge', in International Law as a Profession, eds. Jean d'Aspremont, Tarcisio Gazzini, André Nollkaemper and Wouter Werner (Cambridge: Cambridge University Press, 2017), 117-159.

Pfordten, Dietmar von der. 'Kant on the Right of Resistance', in Kant's Theory of Law, eds. Jean-Christophe Merle and Alexandre Trivisonno (Stuttgart: Franz Steiner Verlag, 2015), 101-119.

Rougier, Antoine. 'La théorie de l'intervention d'humanité'. Revue génerale de droit international public 17 (1910), 468-526.

Schroeder, Paul W. The Transformation of European Politics. 1763-1848 (Oxford: Oxford University Press, 1994).

Schulz, Matthias. Normen und Praxis. Das Europäische Konzert der Großmächte als Sicherheitsrat, 1815-1860 (Berlin: De Gruyter, 2009).

Shahabuddin, Mohammad. Ethnicity and International Law. Histories, Politics and Practices (Cambridge: Cambridge University Press, 2016).

Simon, Hendrik. 'The Myth of Liberum Ius ad Bellum: Justifying War in 19th-Century Legal Theory and Political Practice'. European Journal of International Law 29(1) (2018), 113-136, https://doi.org/10.1093/ejil/chyoog.

Simon, Hendrik. Der Mythos vom "freien Recht zum Krieg”. Zu einer Genealogie der modernen Kriegslegitimation (forthcoming).

Singh, Prabhakar and Benoît Mayer, eds. Critical International Law. Postrealism, Postcolonialism, and Transnationalism (Oxford: Oxford University Press, 2014).

Summers, James. Peoples and International Law: How Nationalism and SelfDetermination Shape a Contemporary Law of Nations (Leiden: Martinus Nijhoff, 2007).

Steiger, Heinhard. 'Ius belli in der Völkerrechtsgeschichte - Universelle Geltung oder Beschränkung auf „anerkannte Kulturvölker“?‘, in Legalität, Legitimität und Moral. Können Gerechtigkeitspostulate Kriege rechtfertigen?, eds. Thomas Bruha, Sebastian Heselhaus and Thilo Marauhn (Tübingen: Mohr Siebeck, 20o8), 59-98.

Tischer, Anuschka. Offizielle Kriegsbegründungen in der Frühen Neuzeit: Herrscherkommunikation in Europa zwischen Souveränität und korporativem Selbstverständnis (Berlin: LIT-Verlag, 2012).

Van Ittersum, Martine Julia. 'The Long Goodbye: Hugo Grotius' Justification of Dutch Expansion Overseas, 1615-1645'. History of European Ideas 36(4) (2010), 386-411.

Vec, Miloš. 'Multinormativität in der Rechtsgeschichte', in Jahrbuch 2008 (Berlin: Berlin-Brandenburgische Akademie der Wissenschaften, 2009), 155-166.

Vec, Miloš. 'Intervention/Nichtintervention, Verrechtlichung der Politik und Politisierung des Völkerrechts im 19. Jahrhundert', in Macht und Recht. Völkerrecht in den internationalen Beziehungen, eds. Ulrich Lappenküper and Reiner Marcowitz (Paderborn: Schöningh, 2010), 135-16o. 
Vec, Miloš. 'Sources in the 19th Century European Tradition: The Myth of Positivism', in The Oxford Handbook of the Sources of International Law, eds. Samantha Besson and Jean d'Aspremont (Oxford: Oxford University Press, 2017), 121-145.

Weber, Max. 'Wissenschaft als Beruf', in Max Weber, Gesamtausgabe, vol. 1, eds. Birgit Morgenbrod, Wolfgang J. Mommsen and Wolfgang Schluchter (Tübingen: Mohr Siebeck, 1992).

Wiener, Antje. Contestation and Constitution of Norms in Global International Relations (Cambridge: Cambridge University Press, 2018).

Yack, Bernard. 'Popular Sovereignty and Nationalism'. Political Theory 29(4) (2011), 517-536.

Zürn, Michael. 'The Politicization of World Politics and its Effects: Eight Propositions'. European Political Science Review 6(1) (2014), 47-71. 